\title{
Effects of metal ions on concentration of DNA in high-conductivity media by capillary electrophoresis
}

\author{
Chih-Ching Huang, Tai-Chia Chiu, Huan-Tsung Chang* \\ Department of Chemistry, National Taiwan University, 10764 Taipei, Taiwan
}

Received 28 November 2001; received in revised form 2 May 2002; accepted 17 May 2002

\begin{abstract}
On-line concentration and separation of DNA prepared in low- or high-conductivity media has been demonstrated using poly(ethylene oxide) (PEO) solution in the presence of electroosmotic flow. DNA fragments migrating against EOF stacked at the boundary between the sample zone and PEO solutions, mainly because of sieving and increases in the viscosity. Unlike conventional methods, the large DNA fragments were detected earlier toward the cathode end in this study. The limit of detection (LOD) at a signal-to-noise ratio $=3$ for $\phi X 174$ RF DNA-Hae III digest prepared in $50 \mathrm{~m} M$ Tris-borate, $\mathrm{pH}$ 10.0, was down to $0.171 \mathrm{ng} / \mathrm{ml}$, with an 860-fold improvement (compared to that obtained by 10 -s injection at $25 \mathrm{~V} / \mathrm{cm}$ ) in the sensitivity, when injecting about $2.58 \mu$ l. By applying a short plug $(2.3 \mathrm{~cm})$ of $0.5 \mathrm{mM} \mathrm{AgNO}_{3}$ prepared in $1.5 \%$ PEO solution after sample injection, the analysis of up to $0.75 \mu \mathrm{l}$ DNA prepared in phosphate-buffered saline (PBS) has been carried out without any tedious desalting processes. This results in an LOD of $6.86 \mathrm{ng} / \mathrm{ml}$ for the DNA sample and a 155 -fold improvement in the sensitivity. Moreover, this method has allowed the analysis of $0.75 \mu \mathrm{l}$ of polymerase chain reaction products amplified after 18 cycles with good reproducibility.
\end{abstract}

(C) 2002 Elsevier Science B.V. All rights reserved.

Keywords: Electroosmotic flow; DNA; Metal cations; Poly(ethylene oxide)

\section{Introduction}

Capillary electrophoresis (CE) compared to highperformance liquid chromatography suffers from low concentration sensitivity, despite its advantages of rapidity, high-resolving power, and lesser amounts of sample and reagents used [1-4]. This is mainly due to small injection volumes (nl) and short optical path lengths (e.g. $75 \mu \mathrm{m})$. To enlarge the optical length, Z-shaped and bubble-cell capillaries have been used $[5,6]$. Owing to the limit of the size of the bubble

*Corresponding author. Tel./fax: + 886-2-2362-1963.

E-mail address: changht@ccms.ntu.edu.tw (H.-T. Chang). cell, diffusion and imperfect distribution of the electric field strength inside the capillary that might cause loss of resolution, sensitivity improvement was not great (only several tens fold). Thus, these methods are not quite useful for DNA analysis such as DNA sequencing and single nucleotide polymorphism (SNP), wherein high-resolving power is of extreme importance [7-10].

Although DNA can be amplified by polymerase chain reaction (PCR), techniques allowing improvements in the sensitivity are always welcomed with respect to speed and cost [11]. So far, a number of friendly on-line electrophoretic concentration techniques have been developed in $\mathrm{CE}$, including iso- 
tachophoretic (ITP) analysis [12,13] and field amplification [14,15]. Although, more than 100-fold improvements in the sensitivity for DNA prepared in low-conductivity media are easily achieved by these techniques, the analysis of DNA prepared in highconductivity media remains problematic, including the loss of resolution, a poor stacking efficiency, and irreproducibility [16-18]. To partially overcome these shortages, the separation could be performed at low electric field strengths or the conductivity of the sample zone must be decreased. The former is not attractive because of slowness and poor stacking efficiency. Titrating tris(hydroxymethyl) aminomethane (Tris) cations used to prepare DNA samples with hydroxide ions was found effective to reduce the conductivity, leading to DNA stacking [19]. One shortage of this method is a low sensitive improvement (less than 100-fold) because the injection length was limited in order to provide a high-resolving power.

Recently, we have developed methods for the separation of large volumes of proteins and DNA in poly(ethylene oxide) (PEO) solution using bare fused-silica capillaries [20-22]. In the presence of electroosmotic flow (EOF), PEO enters the capillary filled with Tris-borate (TB) buffer from the anode end after DNA injection. With small migration mobilities (EOF mobility minus the electrophoretic mobility of DNA), DNA fragments migrate in PEO solutions, resulting in decreases in the electrophoretic mobilities. As a result, DNA stacks at the interface between the sample zone and PEO solutions. In contrast to conventional methods (in the absence of EOF), large DNA fragments are detected earlier in the cathode end because DNA migrates against EOF. We have pointed out that poor concentration, irreproducibility, and loss of resolution are problematic when injecting large-volume samples prepared in low-conductivity media. These problems are mainly due to PEO adsorption on the capillary wall and have been partially overcome by using high concentrations of TB buffers to fill the capillary and to prepare PEO solution, and by preparing DNA in a buffer with a suitable conductivity [22,23]. More recently, we have demonstrated the separation of DNA up to $5 \mu$, with a sensitivity improvement up to 450-fold, using a $150-\mu \mathrm{m}$ capillary [24].

Our methods work well for the analysis of large volumes of DNA or proteins prepared in low-conductivity media, but not for that prepared in highconductivity media [22]. This is mainly due to a small DNA migration in high-conductivity media. To overcome this shortage, techniques based on switching the polarity after removing large amounts of background electrolytes have been developed $[25,26]$. Alternatively, we described a method similar to our previous ones for the analysis of up to about $0.75 \mu \mathrm{l}$ DNA prepared in high-conductivity media [20-22]. We have found the importance of applying a plug of $\mathrm{AgNO}_{3}$ solution between the sample zone and PEO solution. To show the feature of this new method, the analysis of large volumes of polymerase chain reaction (PCR) product was also demonstrated.

\section{Materials and methods}

\subsection{Apparatus}

The basic design of the separation system has been previously described [27]. Briefly, a high-voltage power supply (Gamma High Voltage Research, Ormond Beach, FL, USA) was used to drive electrophoresis. The entire detection system was enclosed in a black box with a high-voltage interlock. The high-voltage end of the separation system was put in a laboratory-made plexiglass box for safety. A 1.5$\mathrm{mW} \mathrm{He}-\mathrm{Ne}$ laser with $543.6 \mathrm{~nm}$ output from Melles Griot (Irvine, CA, USA) was used for excitation. The light was collected with a $10 \times$ objective (numeric aperture $=0.25$ ). One RG 610 cut-off filter was used to block scattered light before the emitted light reaches the photomultiplier tube (Hamamatsu R928). The amplified currents were transferred directly through a 10-k $\Omega$ resistor to a 24-bit A/D interface at $10 \mathrm{~Hz}$ (Borwin, JMBS Developments, Le Fontanil, France) and stored in a personal computer. Capillaries (Polymicro Technologies, Phoenix, AZ, USA) of $75 \mu \mathrm{m}$ I.D. and $365 \mu \mathrm{m}$ O.D. were used for DNA separations without any further coating process. The capillary length was $60 \mathrm{~cm}(50 \mathrm{~cm}$ of effective length).

\subsection{Materials}

PEO with molecular mass $8,000,000$ and other 
chemicals for preparing buffer solutions were from Aldrich (Milwaukee, WI, USA). Ethidium bromide (EtBr) was obtained from Molecular Probes (Eugene, OR, USA). Please note that wearing gloves is required when handling EtBr because it is a highly carcinogenic compound. TB buffers prepared from Tris were adjusted with boric acid to $\mathrm{pH} 10.0$ and 9.0 , respectively. Unless otherwise noted, an $\mathrm{X} \mathrm{mM}$ TB buffer herein means a buffer containing $\mathrm{X} \mathrm{m} M$ Tris adjusted with suitable amounts of boric acid. Phosphate-buffered saline (PBS), $\mathrm{pH} 7.4$, was prepared by dissolving $8.0 \mathrm{~g}$ of $\mathrm{NaCl}, 0.2 \mathrm{~g}$ of $\mathrm{KH}_{2} \mathrm{PO}_{4}$, $0.46 \mathrm{~g}$ of $\mathrm{Na}_{2} \mathrm{HPO}_{4}$, and $0.2 \mathrm{~g}$ of $\mathrm{KCl}$ in 11 of $\mathrm{H}_{2} \mathrm{O}$. PEO solutions were prepared in the TB buffers containing $5 \mu \mathrm{g} / \mathrm{ml}$ EtBr. $\phi X 174$ RF DNA-Hae III digest $(500 \mu \mathrm{g} / \mathrm{ml})$ was purchased from Pharmacia Biotech (Uppsala, Sweden). QIAamp DNA Blood mini kit was purchased from QIAGEN (Hilden, Germany). PCR kits were obtained from Promega (Madison, WI, USA).

\subsection{Preparation of PEO solutions}

Certain amounts of PEO were gradually added into the TB buffer, $\mathrm{pH} 9.0$, in a beaker stirring in a water bath at 85 to $90{ }^{\circ} \mathrm{C}$. During the addition of PEO, a magnetic stirring rod was used to produce a well homogeneous suspension. After addition was complete, the suspension was stirred for at least one more hour. Finally, polymer solutions were degassed with a vacuum system in an ultrasonic tank. Polymer solutions stored in a refrigerator at $4{ }^{\circ} \mathrm{C}$ were usable for at least 3 days.

\subsection{Stacking and separation}

New capillaries were treated with $0.5 M \mathrm{NaOH}$ overnight. Prior to analysis, the base was flushed out with $400 \mathrm{~m} M$ TB buffer, $\mathrm{pH} 10.0$, by pressure means for $20 \mathrm{~s}$. DNA samples were injected into the capillary filled with $400 \mathrm{~m} M$ TB buffers, $\mathrm{pH} 10.0$, by electrokinetic means at 25 or $250 \mathrm{~V} / \mathrm{cm}$ for certain times $(10-120 \mathrm{~s})$. The estimated injection volume was calculated from the injection length and the capillary I.D. [22]. When a short plug of $\mathrm{AgNO}_{3}$ was applied after sample injection as shown in Fig. 1, electrokinetic injection was carried out at $250 \mathrm{~V} / \mathrm{cm}$ for $60 \mathrm{~s}$. During the separation at $333 \mathrm{~V} / \mathrm{cm}$, PEO

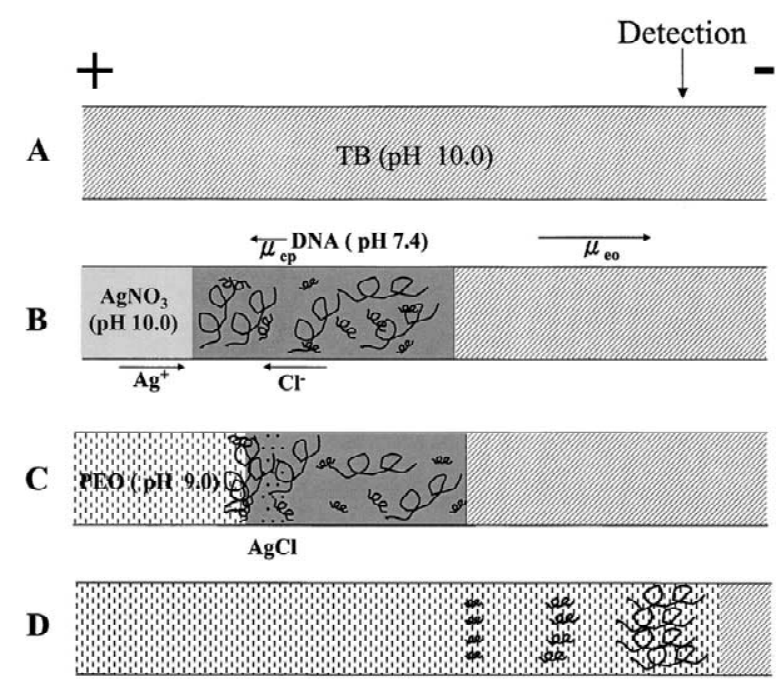

Fig. 1. Schematic of on-line concentration of DNA using PEO under discontinuous conditions. (A) Capillary is filled with 400 $\mathrm{m} M$ TB, pH 10.0, prior to DNA injection. (B) Discontinuous plugs are existent in the capillary after subsequent injections of DNA and a short plug of $\mathrm{AgNO}_{3}$. (C) $\mathrm{AgCl}$ particles form and DNA stacks mainly because of sieving and increases in the viscosity. (D) Separation of the stacked DNA takes place based on the sieving mechanism in CE. $\mu_{\text {ео }}$ and $\mu_{\text {ep }}$ represent the EOF mobility and the electrophoretic mobility of the DNA fragments, respectively.

solutions entered the capillary from the anode end by EOF and acted as sieving matrices. After each run, capillaries were washed with $0.5 M \mathrm{NaOH}$ at 25 $\mathrm{V} / \mathrm{cm}$ for $10 \mathrm{~min}$ to remove PEO solutions and refresh the capillary wall. This treatment has been shown useful for reproducibility, with a relative standard deviation (RSD) of EOF less than $2.0 \%$.

\subsection{DNA extraction and PCR products}

The blood sample was from a normal male. Human genomic DNA from buffy coat was extracted using the QIAamp DNA blood mini kit in accordance with the manufacturer's instructions. Amplification of the DNA sample was conducted as suggested by the manufacturer. Briefly, 22.5 $\mu \mathrm{l}$ PCR master mix component was prepared by mixing $17.45 \mu \mathrm{l}$ sterile water, $2.50 \mu \mathrm{l}$ STR $10 \times$ buffer, $2.50 \mu \mathrm{l}$ TH01 $10 \times$ primer pair, and $0.05 \mu \mathrm{Taq}$ polymerase (5 $\mathrm{U} / \mu \mathrm{l})$. To the PCR master mix, $2.5 \mu \mathrm{l}$ of human genomic DNA (25 ng) were added. PCR was 
conducted as: initial incubation at $96{ }^{\circ} \mathrm{C}$ for $2 \mathrm{~min}$; cycling for the first 10 cycles at $94{ }^{\circ} \mathrm{C}$ for $1 \mathrm{~min}$, at $64{ }^{\circ} \mathrm{C}$ for $1 \mathrm{~min}$, and at $70{ }^{\circ} \mathrm{C}$ for $1.5 \mathrm{~min}$; and cycling for the last eight or 22 cycles at $90{ }^{\circ} \mathrm{C}$ for 1 min, at $64{ }^{\circ} \mathrm{C}$ for $1 \mathrm{~min}$, and at $70{ }^{\circ} \mathrm{C}$ for $1.5 \mathrm{~min}$.

\section{Results and discussion}

\subsection{Matrix effect}

The on-line concentration of DNA in the presence of EOF described here is based on the decrease in the electrophoretic mobility of DNA mainly due to sieving and increases in the viscosity when migrating from the sample zone to the polymer solution $[20,22]$. It is thus important to select a suitable polymer solution for optimum concentration and separation. One other critical consideration when applying this method is adsorption of polymer molecules on the capillary wall mainly due to hydrogen bonding and hydrophobic patches, leading to a small EOF mobility and difficulty of refreshing the capillary wall. In this aspect, use of hydrophilic polymers such as PEO and hydroxyethylcellulose is more appropriate [28]. It has been shown that the adsorption is profound at low ionic strengths and sample matrix plays a crucial role in determining migration time, resolution, and stacking when injecting a large volume of DNA [22]. Table 1 shows the results when using a number of TB buffers, $\mathrm{pH} 7.0$ to 11.0 , to prepare DNA samples. At the same $\mathrm{pH}$, migration times became shorter due to reduced PEO adsorption, while resolution decreased with increasing ionic strength (concentration). In terms of sensitivity improvement (injection volume up to about $1.86 \mu \mathrm{l}$ ) and resolution, TB buffers of 5-10 mM, pH 10.0 and 11.0, are superior. On the other hand, the injection volumes were much less when DNA samples were prepared in TB buffers, $\mathrm{pH} 7.0,8.0$, and 9.0 (10 and $25 \mathrm{~m} M$ Tris). This indicated the use of high amounts of boric acid to prepare DNA samples is not suitable. The limit of injection volume is also due to the small electrophoretic mobility of the DNA fragments at low $\mathrm{pH}$ (or high ionic strength). Please note that the analysis is also not favored at low $\mathrm{pH}$ because of the relatively low quantum yields of intercalated DNA fragments at $\mathrm{pH} 7.0$ and 8.0.

As the goal of this work aimed to the development of a method allowing sensitivity improvement for the

Table 1

Effect of the sample matrix on injection volume, peak height, bandwidth, resolution, and migration time using a 60-cm capillary

\begin{tabular}{|c|c|c|c|c|c|c|c|c|c|c|c|c|c|c|c|}
\hline \multirow[t]{2}{*}{$\mathrm{pH}$} & \multirow{2}{*}{$\begin{array}{l}\text { TB } \\
(\mathrm{m} M)\end{array}$} & \multirow{2}{*}{$\begin{array}{l}\text { Borate } \\
(\mathrm{m} M)\end{array}$} & \multirow{2}{*}{$\begin{array}{l}V^{\mathrm{a}} \\
(\mu \mathrm{l})\end{array}$} & \multicolumn{3}{|c|}{ Peak height (mV) } & \multicolumn{3}{|c|}{ Bandwidth (min) } & \multicolumn{3}{|l|}{ Resolution } & \multicolumn{3}{|c|}{ Migration time (min) } \\
\hline & & & & $1353^{\mathrm{b}}$ & $271^{\mathrm{b}}$ & $72^{b}$ & 1353 & 271 & 72 & $1353 / 1078$ & $271 / 281$ & $118 / 72$ & $t_{0}{ }^{\mathrm{c}}$ & $t_{1353}{ }^{\mathrm{d}}$ & $t_{72}^{\mathrm{d}}$ \\
\hline \multirow[t]{2}{*}{7.0} & 5.0 & 26.5 & 0.46 & 140.5 & 4.9 & 2.0 & 0.02 & 0.11 & 0.22 & 1.84 & 0.96 & 12.12 & 19.51 & 22.27 & 31.11 \\
\hline & 10.0 & 53.0 & 0.02 & 20.1 & 1.4 & 1.0 & 0.03 & 0.03 & 0.07 & 1.22 & 6.29 & 62.34 & 14.12 & 16.86 & 24.97 \\
\hline \multirow[t]{3}{*}{8.0} & 5.0 & 9.0 & 0.62 & 155.0 & 3.7 & 2.7 & 0.01 & 0.08 & 0.08 & 5.02 & 6.91 & 18.24 & 30.04 & 32.75 & 42.24 \\
\hline & 10.0 & 18.0 & 0.15 & 67.6 & 1.8 & 1.7 & 0.02 & 0.05 & 0.06 & 2.36 & 6.76 & 55.17 & 16.42 & 19.25 & 28.06 \\
\hline & 25.0 & 45.0 & 0.05 & 13.1 & 1.3 & 0.7 & 0.03 & 0.07 & 0.09 & 1.95 & 5.25 & 14.37 & 14.87 & 17.57 & 26.15 \\
\hline \multirow[t]{3}{*}{9.0} & 5.0 & 4.1 & 1.86 & 574.8 & 20.1 & 18.8 & 0.03 & 0.02 & 0.04 & 4.99 & 5.40 & 55.03 & 70.85 & 74.35 & 85.63 \\
\hline & 10.0 & 8.2 & 0.93 & 859.9 & 10.0 & 8.6 & 0.02 & 0.07 & 0.05 & 3.54 & 1.90 & 27.43 & 56.93 & 59.83 & 70.94 \\
\hline & 25.0 & 20.5 & 0.46 & 151.1 & 3.9 & 1.8 & 0.03 & 0.11 & 0.16 & 1.45 & 1.09 & 20.45 & 24.27 & 27.67 & 37.97 \\
\hline \multirow[t]{3}{*}{10.0} & 5.0 & 0.3 & 1.86 & 1223.2 & 21.9 & 40.3 & 0.04 & 0.03 & 0.04 & 3.33 & 3.89 & 43.27 & 65.56 & 66.77 & 75.12 \\
\hline & 10.0 & 0.6 & 1.86 & 1224.3 & 54.5 & 53.6 & 0.03 & 0.02 & 0.03 & 2.18 & 5.44 & 54.23 & 50.18 & 51.30 & 58.37 \\
\hline & 25.0 & 1.5 & 1.86 & 1184.7 & 444.3 & 48.7 & 0.04 & 0.02 & 0.04 & 0.96 & 6.65 & 56.15 & 43.03 & 45.98 & 56.74 \\
\hline \multirow[t]{3}{*}{11.0} & 5.0 & 0.3 & 1.86 & 1203.3 & 67.8 & 35.1 & 0.02 & 0.04 & 0.03 & 3.29 & 4.35 & 56.98 & 63.57 & 66.16 & 75.05 \\
\hline & 10.0 & 0.6 & 1.86 & 1205.5 & 122.2 & 40.2 & 0.02 & 0.03 & 0.03 & 2.78 & 4.86 & 53.32 & 51.22 & 53.60 & 60.13 \\
\hline & 25.0 & 1.5 & 1.86 & 1208.2 & 523.1 & 45.4 & 0.01 & 0.03 & 0.05 & 0.73 & 8.17 & 40.62 & 34.97 & 37.72 & 46.38 \\
\hline
\end{tabular}

\footnotetext{
${ }^{\mathrm{a}}$ Maximum injection volume.

b 1353,271 , and 72 represent the 1353-, 271-, and 72-bp fragments, respectively.

${ }^{\mathrm{c}}$ Time when the baseline shifted.

${ }^{\mathrm{d}}$ Migration times for the 1353- and 72-bp fragments, respectively.
} 
analysis of DNA in biological samples without sample pretreatment, it is required to optimize the condition for increasing injection volumes at $\mathrm{pH}$ 7.4. Although Table 1 shows that DNA stacked when injecting DNA up to $0.46 \mu \mathrm{l}$ at $\mathrm{pH} 7.0$, the maximum injection volumes for biological samples should be different, depending on matrix. To explore the impact of salts on concentration and separation of DNA, $5 \mathrm{~m} M$ TB buffers, $\mathrm{pH}$ 7.4, containing different salts, including sodium chloride, sodium phosphate, and sodium acetate, were tested. Table 2 shows that the separation became faster with increasing the concentrations of salts when injecting $0.62 \mu \mathrm{l}$ DNA. With increasing the concentration of salts, PEO adsorption decreased, leading to a greater EOF mobility. It should be pointed out that higher and sharper peak profiles were achieved at higher concentrations of salts when adding the same species. This indicated that ITP occurred. In addition, greater quantum yields of intercalated DNA fragments at high salts should be taken into account [29]. However, peak splitting was problematic when using TB buffers containing $50.0 \mathrm{~m} M$ sodium phosphate or sodium acetate. To this end, we should point out that the effect of $\mathrm{pH}$ changes on the stacking efficiency should not be ignored [30].

\subsection{Effect of metal ions}

Next, we tested the analysis of $0.75 \mu \mathrm{DNA}$ prepared in PBS by this proposed method, with a disappointing result as shown in Fig. 2A. Possible reasons include a significantly differential conductivity between the sample zone and PEO as well as small electrophoretic mobilities of the DNA frag- ments in high-conductivity media (the major salt is $\mathrm{NaCl}, 138 \mathrm{mM}$ ). To reduce the effect of $\mathrm{Cl}^{-}$, we tested the possibility of forming $\mathrm{AgCl}$ particles with $\mathrm{Ag}^{+}$inside the capillary during the analysis. This was done by injecting a short plug $(3.25 \mathrm{~cm})$ of $\mathrm{AgNO}_{3}$ prepared in $25 \mathrm{~m} M \mathrm{~TB}, \mathrm{pH} 10.0$, after DNA injection. Fig. $2 \mathrm{~B}$ and $\mathrm{C}$ show very impressive results, while $2 \mathrm{D}$ and $\mathrm{E}$ demonstrate less successfully. It is interesting to note that the peak heights for the $72-310$ base pair (bp) fragments increased with increasing the concentration of $\mathrm{AgNO}_{3}$ up to $1 \mathrm{mM}$, while some peaks split and declined at greater than $1 \mathrm{~m} M$. We inferred that the short plug of $\mathrm{AgNO}_{3}$ should play a significant role in affecting stacking and resolution. The plug acted as a water plug that has been shown in other studies to increase the stacking efficiency $[31,32]$, wherein the velocity of the DNA fragments accelerated when migrating from the sample zone to the low-conductivity plug. However, we have to mention that applying a short plug of water did not work by this method. In addition, $\mathrm{pH}$ changes and sample self stacking may be contributors $[16,30]$. It is also very possible that $\mathrm{AgCl}$ particles formed once $\mathrm{Ag}^{+}$from the plug interacted with $\mathrm{Cl}^{-}$from the sample zone, with a support of the existence of a small, wide and noisy peak after the baseline shifted (not shown). As a result, the DNA fragments might interact with $\mathrm{AgCl}$ particles, leading to very sharp peaks and enhanced stacking efficiency. At high concentrations, greater amounts of particles might form and thus interact strongly with DNA, which caused peak splitting for the large DNA fragments. To support our reasoning, we injected a short plug of $0.5 \mathrm{~m} M \mathrm{NaNO}_{3}$ at concentrations ranging 0-2 $\mathrm{mM}$ instead of $\mathrm{AgNO}_{3}$. In the range of

Table 2

Effect of salts on peak height, bandwidth, resolution, and migration time using a 60-cm capillary

\begin{tabular}{|c|c|c|c|c|c|c|c|c|c|c|c|c|c|}
\hline & & \multicolumn{3}{|c|}{ Peak height $(\mathrm{mV})$} & \multicolumn{3}{|c|}{ Bandwidth (min) } & \multicolumn{3}{|l|}{ Resolution } & \multicolumn{3}{|c|}{ Resolution } \\
\hline & & 1353 & 271 & 72 & 1353 & 271 & 72 & $1353 / 1078$ & $271 / 281$ & $118 / 72$ & $t_{0}$ & $t_{1353}$ & $t_{72}$ \\
\hline \multirow[t]{3}{*}{ Sodium chloride $(\mathrm{m} M)$} & 1.0 & 124.6 & 8.9 & 3.3 & 0.04 & 0.13 & 0.22 & 4.42 & 1.16 & 72.18 & 25.72 & 28.71 & 39.48 \\
\hline & 10.0 & 335.2 & 34.1 & 15.8 & 0.04 & 0.06 & 0.04 & 1.75 & 5.41 & 65.72 & 22.40 & 25.50 & 36.40 \\
\hline & 50.0 & 1180.8 & 386.7 & 12.7 & 0.02 & 0.01 & 0.05 & 2.71 & 11.21 & 40.54 & 17.10 & 22.59 & 32.35 \\
\hline \multirow[t]{2}{*}{ Sodium phosphate $(\mathrm{m} M)$} & 1.0 & 501.7 & 11.2 & 4.3 & 0.02 & 0.08 & 0.10 & 1.57 & 2.19 & 27.37 & 27.08 & 30.32 & 42.13 \\
\hline & 10.0 & 1229.0 & 552.5 & 22.2 & 0.02 & 0.02 & 0.04 & 4.33 & 13.73 & 58.52 & 24.84 & 29.52 & 42.49 \\
\hline \multirow[t]{2}{*}{ Sodium acetate $(\mathrm{m} M)$} & 1.0 & 136.2 & 3.5 & 1.3 & 0.04 & 0.12 & 0.23 & 2.51 & 2.97 & 68.53 & 26.99 & 30.04 & 41.28 \\
\hline & 10.0 & 865.6 & 226.4 & 15.0 & 0.03 & 0.03 & 0.04 & 4.25 & 6.64 & 61.88 & 24.98 & 28.60 & 41.17 \\
\hline
\end{tabular}




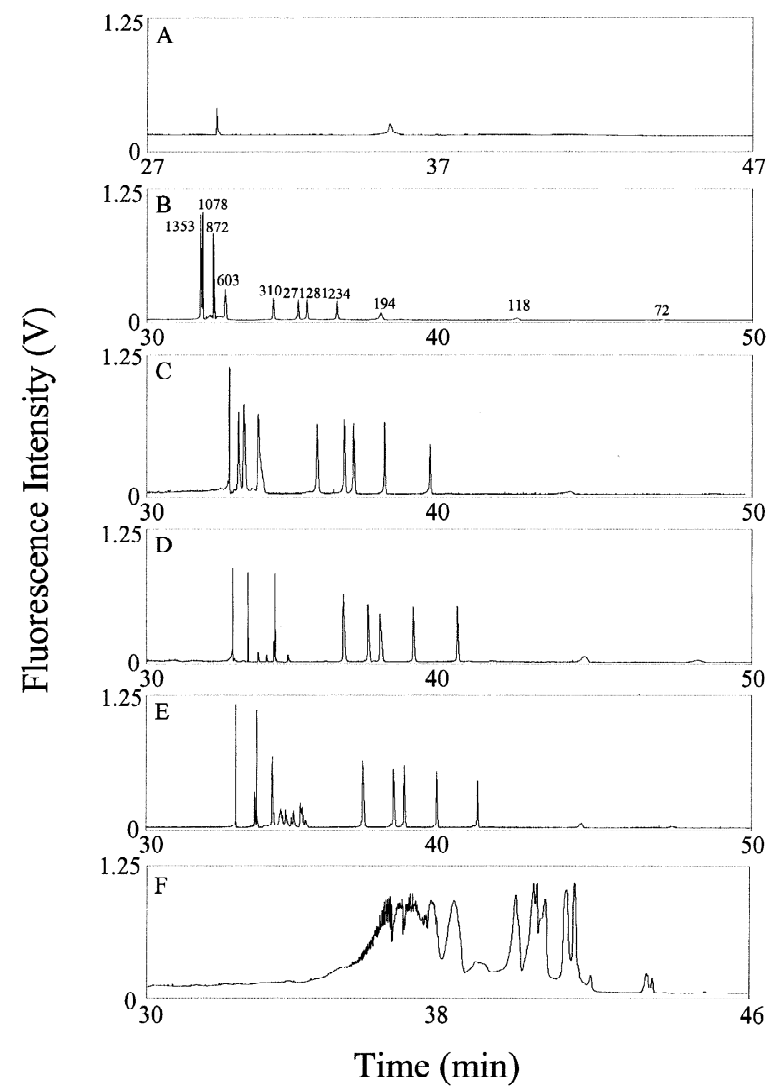

Fig. 2. Effect of the plug composition on DNA stacking at 333 $\mathrm{V} / \mathrm{cm}$ using $1.5 \%$ PEO solution prepared in $200 \mathrm{~m} M \mathrm{~TB}, \mathrm{pH} 9.0$, containing $5 \mu \mathrm{g} / \mathrm{ml} \mathrm{EtBr}$. Capillary: $60 \mathrm{~cm}$ of total length, $50 \mathrm{~cm}$ of effective length, $75 \mu \mathrm{m}$ of inner-diameter, and filled with 400 $\mathrm{m} M$ TB, pH 10.0. One $\mu \mathrm{g} / \mathrm{ml} \phi \mathrm{X} 174$ RF DNA-Hae III digest prepared in PBS was injected at $250 \mathrm{~V} / \mathrm{cm}$ for $120 \mathrm{~s}(0.75 \mu \mathrm{l})$. Plugs of $\mathrm{AgNO}_{3}$ prepared in $25 \mathrm{~m} M \mathrm{~TB}, \mathrm{pH} 10.0$, were injected at $250 \mathrm{~V} / \mathrm{cm}$ for $60 \mathrm{~s}$ after sample injection, with $\left[\mathrm{AgNO}_{3}\right]=0 \mathrm{mM}$ in $\mathrm{A}, 0.1 \mathrm{~m} M$ in $\mathrm{B}, 0.5 \mathrm{~m} M$ in $\mathrm{C}, 1 \mathrm{~m} M$ in $\mathrm{D}$, and $2 \mathrm{~m} M$ in E. A plug of $0.5 \mathrm{~m} M \mathrm{NaNO}_{3}$ prepared in $25 \mathrm{~m} M \mathrm{~TB}$, pH 10.0, was injected at $250 \mathrm{~V} / \mathrm{cm}$ for $60 \mathrm{~s}$ after sample injection in $\mathrm{F}$.

0-0.5 $\mathrm{mM}$, the sensitivity for small DNA fragments increased, while the loss of resolution was problematic. Fig. 2F represents one of the best results using $\mathrm{NaNO}_{3}$ plugs, with broad and unresolved peaks for the large DNA fragments that indicate poor stacking. When the concentrations of $\mathrm{NaNO}_{3}$ were further increased from 0.5 to $1.0 \mathrm{~m} M$, the resolution decreased and only a very broad peak was found at 1.0 $\mathrm{m} M$, again indicating poor stacking.

To further evaluate the effect of $\mathrm{AgNO}_{3}$ on DNA stacking, we increased the plug length of $0.5 \mathrm{mM}$

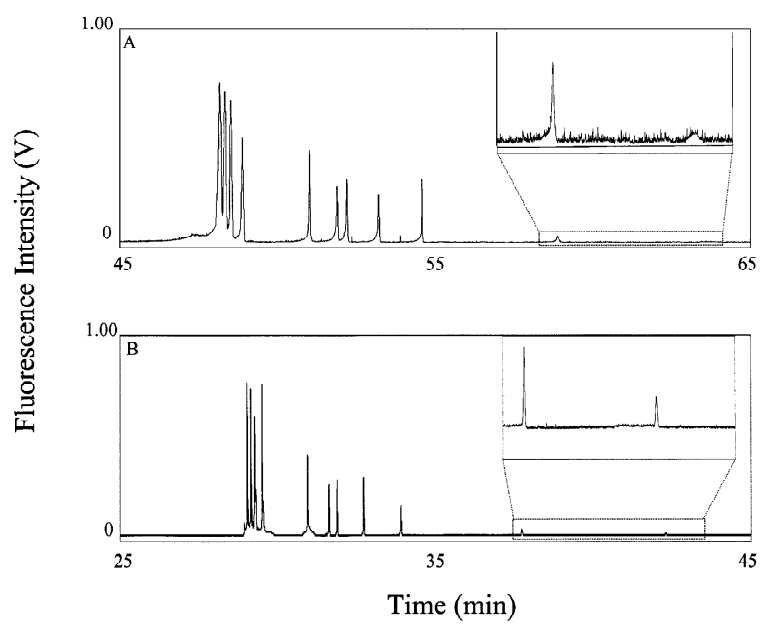

Fig. 3. Effect of the length and composition of $\mathrm{AgNO}_{3}$ plug on DNA concentration and separation. (A) $\mathrm{AgNO}_{3}$ prepared in 25 $\mathrm{m} M$ TB, pH 10.0, was injected at $250 \mathrm{~V} / \mathrm{cm}$ for $90 \mathrm{~s}$; (B) $\mathrm{AgNO}_{3}$ prepared in $1.5 \%$ PEO dissolved in $200 \mathrm{mM}$ TB, pH 9.0, was injected at $250 \mathrm{~V} / \mathrm{cm}$ for $60 \mathrm{~s}$. Other conditions were as in Fig. 2.

$\mathrm{AgNO}_{3}$ prepared in $25 \mathrm{~m} M \mathrm{~TB}, \mathrm{pH}$ 10.0. Compared to Fig. 1C, Fig. 3A shows that increases in the plug length did not provide better stacking, but caused a longer separation time (64 $\mathrm{min})$. This is because PEO adsorption increased when the low-conductivity plug of $\mathrm{AgNO}_{3}$ was increased. On the other hand, the separation time was shortened to 44 min shown in Fig. 3B when injecting $0.5 \mathrm{mM} \mathrm{AgNO}_{3}$ prepared in $1.5 \%$ PEO dissolved in $200 \mathrm{~m} M \mathrm{~TB}, \mathrm{pH} 9.0$. The result indicates that our first reasoning about the role of $\mathrm{AgNO}_{3}$ plug in increasing injection volumes addressed above is not the main reason. In comparison to broad and unresolved peaks obtained without applying such a plug (not shown), the result also shows the important role that $\mathrm{AgNO}_{3}$ played in determining stacking. It is important to emphasize that the peak corresponding to the small DNA fragments were sharper and greater (about 10 times higher for the 72-bp fragments) when compared to that applying a plug of $0.5 \mathrm{mM} \mathrm{AgNO}_{3}$ prepared in $25 \mathrm{~m} M$ TB buffer, $\mathrm{pH}$ 10.0. With a faster separation result, this again supports that PEO adsorption is more pronounced at low ionic strengths.

\subsection{Linearity}

When DNA samples prepared in $50 \mathrm{~m} M \mathrm{~TB}, \mathrm{pH}$ 
Table 3

Linearity, reproducibility, and efficiency for the analysis of DNA prepared in $50 \mathrm{~m} M \mathrm{~TB}$, pH 10.0 using an 80-cm capillary

\begin{tabular}{|c|c|c|c|}
\hline & \multicolumn{3}{|l|}{ DNA (bp) } \\
\hline & 1353 & 271 & 72 \\
\hline Linear regression $^{\mathrm{a}}$ & $y=679.85 x+3.23$ & $y=574.26 x+2.44$ & $y=99.34 x+1.39$ \\
\hline$R^{2}$ & 0.997 & 0.998 & 0.997 \\
\hline$\%$ RSD (peak height, $n=5)^{\mathrm{b}}$ & 3.6 & 3.8 & 2.9 \\
\hline$\%$ RSD (migration time, $n=5$ ) ${ }^{\mathrm{b}}$ & 3.4 & 3.9 & 3.2 \\
\hline Theoretical plates ${ }^{\mathrm{b}}$ & $5.7 \times 10^{6}$ & $3.1 \times 10^{6}$ & $1.7 \times 10^{6}$ \\
\hline
\end{tabular}

${ }^{\mathrm{a}} y$, peak height $(\mathrm{mV}) ; x$, injection volume $(\mu \mathrm{l})$.

${ }^{\mathrm{b}} 2.58 \mu \mathrm{l}$ of $1.0 \mu \mathrm{g} / \mathrm{ml} \phi \mathrm{X} 174 \mathrm{RF}$ DNA-Hae III digest injected.

10.0, were electrokinetically injected, the peak height is proportional to the injection volume up to $2.58 \mu \mathrm{l}$ as shown in Table 3. For example, linear relationships between the injection volume and the peak heights corresponding to 1353-, 271-, and 72-bp fragments were obtained, with $R^{2}>0.997$. The reproducibility of this method was reasonable in terms of migration time and peak height $(\mathrm{RSD}<4.0 \%)$. The fact that the theoretical plates for all the DNA fragments were greater than 1 million while injecting $2.58 \mu \mathrm{l}$ DNA further suggests that all DNA stacked without significant loss of the separation efficiency. On the basis of the peak height corresponding to the 72-bp fragment, the limit of detection (LOD) at a signal-to-noise ratio $(S / N)=3$ for the DNA sample was $0.171 \mathrm{ng} / \mathrm{ml}$. This was about an 860 -fold sensitivity improvement compared to that by a conventional injection (10-s injection). However the analysis was slow (about $140 \mathrm{~min}$ ). Fig. 4 depicts linearity between the peak height and the injection volume when injecting $0.5 \mathrm{mM} \mathrm{AgNO}_{3}$ at $250 \mathrm{~V} / \mathrm{cm}$ for $60 \mathrm{~s}$ after injection of DNA prepared in PBS. Linearity with $R^{2}>0.97$ was obtained for the 1353-, 271-, and 72-bp fragments, over the volume range of $0-0.75 \mu$ l. As $0.75 \mu l$ DNA was injected, the LOD was $6.86 \mathrm{ng} / \mathrm{ml}$ on the basis of the peak height corresponding to the 72-bp fragment. This was about a 155 -fold sensitivity improvement compared to that by a conventional injection.

\subsection{Stacking of PCR products}

To show the feasibility of this method with a short plug of $\mathrm{AgNO}_{3}$ for the analysis of real biological samples, we injected and separated $0.75-\mu l$ PCR products that were amplified after 18 cycles. Fig. 5 clearly shows that there are two peaks between 24 and $25 \mathrm{~min}$. The RSD values $(n=3)$ for the peak height and migration time for the first one were 3.1 and $2.2 \%$, respectively. It is important to note that the PCR cycle performed in this study was much less than the one ( 32 cycles) suggested by the manufacturer. Advantages over greater amplification cycles include a shorter analysis time (PCR, concentration and separation), shortening from $122.7 \mathrm{~min}$ to 92.5 min, less costs (less consumption of primer, template, and other reagents), and a low risk of contaminants $[33,34]$. To identify the two peaks shown in Fig. 5, we spiked $\phi X 174$ RF DNA-Hae III digest into the PCR product and performed the analysis (result not shown). Comparing the migration times for these two peaks to that for 234- and 194-bp fragments from the standard, we assigned these two

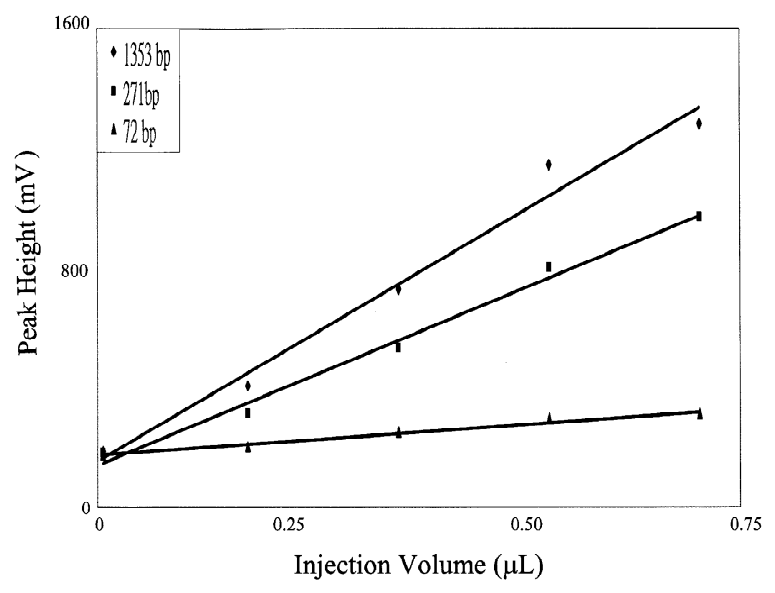

Fig. 4. Linearity between peak height and injection volume. Conditions were as in Fig. 3B. 


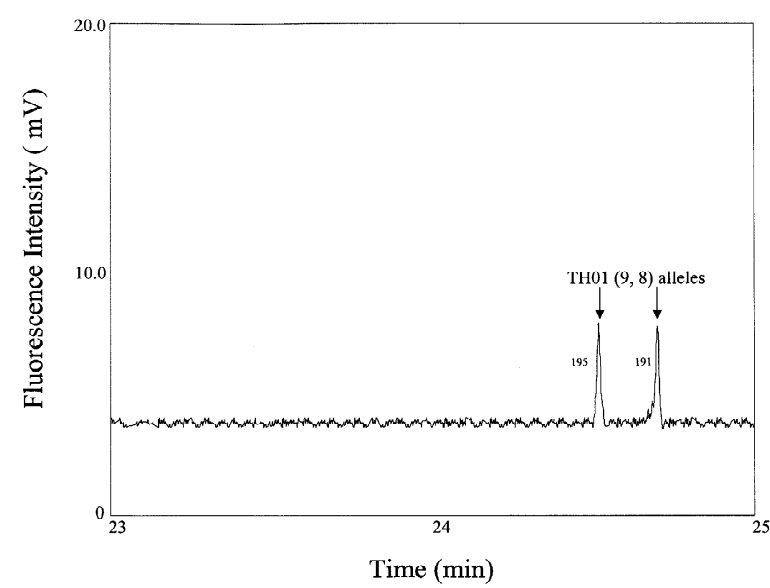

Fig. 5. Separation of $0.75-\mu l$ PCR products amplified after 18 cycles at $333 \mathrm{~V} / \mathrm{cm}$ using $1.5 \%$ PEO prepared in $200 \mathrm{mM}$ TB solution, $\mathrm{pH}$ 9.0. Other conditions were as in Fig. 3B.

peaks to TH01 $(9,8)$ allele, with 195- and 191-bp fragments, respectively.

\section{Conclusions}

We have found that matrices containing suitable amounts of salts like $\mathrm{NaCl}$ are essential for largevolume injection and rapid analysis, due in part to reduced PEO adsorption. Salts not only affect resolution, peak asymmetry, migration time, and stacking efficiency, but also affect the interactions with the capillary wall and the fluorescence characteristics of intercalated DNA fragments. However, large amounts of salts would cause small electrophoretic mobilities of the DNA fragments migrating from the sample zone to PEO solution and peak splitting, thereby limiting the injection volume. These problems have been partially solved by injection of a short plug of $\mathrm{AgNO}_{3}$ after sample injection. As a result, it allows the analysis of up to $0.75-\mu l$ DNA samples prepared in PBS or PCR products without desalting. The results have proved this method provides the advantages of simplicity, robustness, reproducibility, and rapidity. Together with a 155fold improvement in the sensitivity, this method is quite promising for analysis and/or recovery of gene amplified after PCR products.

\section{Acknowledgements}

This work was supported by the National Science Council of Taiwan under contract number NSC 902113-M002-058.

\section{References}

[1] D. Liang, L. Song, Z. Chen, B. Chu, Electrophoresis 22 (2001) 1997.

[2] C. Gelfi, A. Orsi, F. Leoncini, P.G. Righetti, J. Chromatogr. A 689 (1995) 97.

[3] M. Chiari, S. Riva, A. Gelain, A. Vitale, E. Turati, J. Chromatogr. A 781 (1997) 347.

[4] Y. Liu, W.G. Kuhr, Anal. Chem. 71 (1999) 1668.

[5] S.E. Moring, R.T. Reel, R.E.J. van Soest, Anal. Chem. 65 (1993) 3454.

[6] R.O. Cole, D.L. Hiller, C.A. Chwojdak, M.J. Sepaniak, J. Chromatogr. A 736 (1996) 239.

[7] X.-C. Li-Sucholeiki, W.G. Thilly, Nucl. Acids Res. 28 (2000) 44.

[8] V. Dolník, J. Biochem. Biophys. Methods 41 (1999) 103.

[9] E. Carrilho, Electrophoresis 21 (2000) 55.

[10] A. Hanning, P. Lindberg, J. Westberg, J. Roeraade, Anal. Chem. 72 (2000) 3423.

[11] A. Zimran, C. Glass, V.S. Thorpe, E. Beutler, Nucl. Acids Res. 17 (1989) 7538.

[12] S. Auriola, I. Jääskeläinen, M. Regina, A. Urtti, Anal. Chem. 68 (1996) 3907.

[13] I. Barme, G.J.M. Bruin, A. Paulus, M. Ehrat, Electrophoresis 19 (1998) 1445.

[14] R.-L. Chien, D.S. Burgi, Anal. Chem. 64 (1992) 1046.

[15] R.-L. Chien, D.S. Burgi, J. Chromatogr. 559 (1991) 141.

[16] J.L. Beckers, P. Boček, Electrophoresis 21 (2000) 2747.

[17] G. Hempel, Electrophoresis 21 (2000) 691.

[18] D.M. Osbourn, D.J. Weiss, C.E. Lunte, Electrophoresis 21 (2000) 2768.

[19] Y. Xiong, S.-R. Park, H. Swerdlow, Anal. Chem. 70 (1998) 3605.

[20] M.-M. Hsieh, W.-L. Tseng, H.-T. Chang, Electrophoresis 21 (2000) 2904.

[21] W.-L. Tseng, H.-T. Chang, Anal. Chem. 72 (2000) 4805.

[22] W.-L. Tseng, M.-M. Hsieh, S.-J. Wang, C.-C. Huang, Y.-C. Lin, P.-L. Chang, H.-T. Chang, J. Chromatogr. A 927 (2001) 179.

[23] W.-L. Tseng, M.-M. Hsieh, S.-J. Wang, H.-T. Chang, J. Chromatogr. A 894 (2000) 219.

[24] C.-C. Huang, M.-M. Hsieh, T.-C. Chiu, Y.-C. Lin, H.-T. Chang, Electrophoresis 22 (2001) 4328.

[25] R.-L. Chien, D.S. Burgi, J. Chromatogr. 559 (1991) 153.

[26] M. Albert, L. Debusschere, C. Demesmay, J.L. Rocca, J. Chromatogr. A 757 (1997) 281.

[27] H.-S. Chen, H.-T. Chang, Anal. Chem. 71 (1999) 2033. 
[28] M.-F. Huang, C.-E. Hsu, W.-L. Tseng, Y.-C. Lin, H.-T. Chang, Electrophoresis 22 (2001) 2281.

[29] M.O. Khan, S.M. Mel'nikov, B. Jönsson, Macromolecules 32 (1999) 8836.

[30] P. Britz-Mckibbin, G.M. Bebault, D.D.Y. Chen, Anal. Chem. 72 (2000) 1729.
[31] R.-L. Chien, D.S. Burgi, Anal. Chem. 64 (1992) 489A.

[32] C.-X. Zhang, W. Thormann, Anal. Chem. 68 (1996) 2523.

[33] G. Lisby, in: S.J. Meltzer (Ed.), PCR in Bioanalysis, Humana Press, New Jersey, 1998, p. 1.

[34] M.J. McPherson, S.G. Møller, in: PCR, Springer-Verlag, New York, 2000, p. 1. 